\title{
Feasibility of MRI attenuation correction in cardiac FDG-PET
}

\author{
Jeffrey M Lau ${ }^{1 *}$, Shivak Sharma ${ }^{1}$, Richard Laforest ${ }^{2}$, Jonathan McConathy ${ }^{2}$, James Barnwell ${ }^{2}$, Agus Priatna ${ }^{3}$, \\ Linda M Becker ${ }^{2}$, Glenn J Foster ${ }^{2}$, Robert J Gropler ${ }^{2}$, Pamela K Woodard ${ }^{2}$ \\ From 16th Annual SCMR Scientific Sessions \\ San Francisco, CA, USA. 31 January - 3 February 2013
}

\section{Background}

Simultaneous acquisition PET-MRI is a new technology that has the potential to significantly impact diagnostic patient care. Cardiac imaging using PET-MRI offers high signal resolution MRI images superimposed on PET metabolic functional assessment. Specifically, 18Ffluorodeoxyglucose (FDG) PET-MR has the potential to provide both anatomic scar tissue evaluation and information regarding myocardial glucose metabolism. While early brain and soft tissue data have demonstrated that PET specific uptake values (SUVs) obtained using MRI for attenuation correction (AC) are comparable to SUVs obtained using CT AC, SUV measurements of myocardial tissue have not been compared. The objective of this pilot study is to determine the reproducibility of SUVs obtained by PET imaging using an AC $\mu$-map comprised of a dual echo VIBE Dixon MRI sequence instead of CT.

\section{Methods}

30 patients with no known cardiac history underwent full body PET-CT imaging (Siemens Biograph 40), followed by full-body simultaneous PET-MRI imaging (Siemens Biograph mMR). A single dose (10-15 mCi) of 18F-FDG radiotracer was injected on average $59+/-7$ minutes prior to PET-CT image acquisition, and127 +/23 minutes prior to PET-MRI image acquisition. Images were whole body images acquired without cardiac gating. For PET-MR the AC $\mu$-map was a dual echo VIBE Dixon sequence that separates water and fat (TE1/TE2 $=1.23 \mathrm{msec} / 2.46 \mathrm{msec}, \mathrm{TR}=3.6 \mathrm{msec}$, left-right FOV = $500 \mathrm{~mm}$, anterior-posterior FOV $=300 \mathrm{~mm}$ ). Average SUVs were obtained by tracing the entire cross section

${ }^{1}$ Cardiology, Washington University in St. Louis, Saint Louis, MO, USA Full list of author information is available at the end of the article of the left ventricular myocardium in the short axis of the heart at the papillary muscle level, using the syngo TRUE-D computer software (Siemens).

\section{Results}

There is no statistically significant difference between the average SUVs obtained by PET-CT and PET-MRI (4.62 vs. $4.68, \mathrm{p}=0.47$ ). Although FDG uptake rate and the SUVs are highly variable among this study group, there is excellent per patient correlation between the values acquired by PET-CT and PET-MRI (R2 $=0.97$, slope $=0.78$, Figure).

\section{Conclusions}

Myocardial PET SUVs measured using MRI as AC show excellent correlation to those obtained by standard PETCT imaging. Future studies will focus on the optimization of cardiac-gated simultaneous PET-MRI image acquisition.

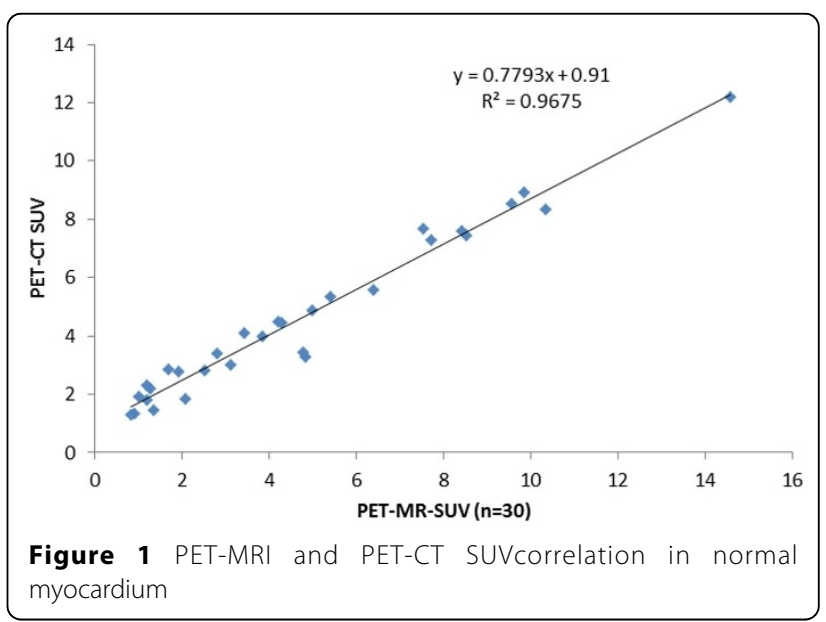

(c) 2013 Lau et al; licensee BioMed Central Ltd. This is an Open Access article distributed under the terms of the Creative Commons :-1Wed Central Attribution License (http://creativecommons.org/licenses/by/2.0), which permits unrestricted use, distribution, and reproduction in any medium, provided the original work is properly cited. 


\section{Funding}

Mallinckrodt Institute of Radiology Departmental Funds.

\section{Author details}

${ }^{1}$ Cardiology, Washington University in St. Louis, Saint Louis, MO, USA.

${ }^{2}$ Radiology, Washington University in St. Louis, Saint Louis, MO, USA.

${ }^{3}$ Siemens, Malvern, PA, USA.

Published: 30 January 2013

doi:10.1186/1532-429X-15-S1-061

Cite this article as: Lau et al.: Feasibility of MRI attenuation correction in cardiac FDG-PET. Journal of Cardiovascular Magnetic Resonance 201315 (Suppl 1):061.

Submit your next manuscript to BioMed Central and take full advantage of:

- Convenient online submission

- Thorough peer review

- No space constraints or color figure charges

- Immediate publication on acceptance

- Inclusion in PubMed, CAS, Scopus and Google Scholar

- Research which is freely available for redistribution

Submit your manuscript at www.biomedcentral.com/submit
() Biomed Central 